\title{
A Review of Environmental Isotopes: Its Prospective Applications in Disaster-risk Management of Watershed
}

\author{
Muhammad Izzuddin Syakir, ${ }^{1,2^{*}}$ Nurul Sufiana Jamian, ${ }^{1}$ Mohd Hafiidz Jaafar, ${ }^{1}$ \\ Mohd Shaiful Yusuff, ${ }^{1}$ Mark Harris Zuknik ${ }^{1}$ and Roslanzairi Mostapa ${ }^{3}$ \\ ${ }^{1}$ Environmental Technology, School of Industrial Technology, Universiti Sains Malaysia, \\ 11800 USM Pulau Pinang, Malaysia \\ ${ }^{2}$ Centre of Global Sustainability Studies (CGSS), Universiti Sains Malaysia, \\ 11800 USM Pulau Pinang, Malaysia \\ ${ }^{3}$ Malaysian Nuclear Agency, Bangi, 43000 Kajang, Selangor, Malaysia \\ *Corresponding author: misyakir@usm.my
}

Published online: 25 November 2018

To cite this article: Syakir, M. I. et al. (2018). A review of environmental isotopes: Its prospective applications in disaster-risk management of watershed. J. Phys. Sci., 29(3), 121-147, https://doi.org/10.21315/jps2018.29.3.10

To link to this article: https://doi.org/10.21315/jps2018.29.3.10

\begin{abstract}
Water is one of the critical resources in the agenda of promoting sustainability. Yet, among all the observed natural and anthropogenic adversities, waterrelated disasters appear as the most recurrent which hinder sustainable socio-economic development goals. Climate change, urban expansion, deforestation and increase in population are thought to be the main factors of water-related disasters. Considering those factors, understanding the hydrologic balance of watersheds and the impact that nature and humanity impose on regional ecosystem becomes one of the important research priorities. This paper reviews the applications of stable isotopes in hydrological studies for catchment management. Advancements in isotope research (origin, flow paths, residence times and water budget), has led to new frontiers in palaeoclimatology and palaeohydrology studies. Future applications hold promise to recognise the patterns of modern and ancient isotopic signatures within ecosystems and provide useful information in understanding potential natural hazards, thus complementing sustainable watershed management.
\end{abstract}

Keywords: Environmental isotopes, ecosystem services, floods, watersheds, sustainability 


\section{INTRODUCTION}

Water quantity and water quality are fundamental issues in hydrology. ${ }^{1,2}$ Complex permutations of stressors (such as urban and agricultural land use, hydropower generation and climate change) have had a tremendous impact on watersheds, thus undermining the resiliency of ecosystems to withstand natural disasters. Climate change can be affected by the annual amount of rainfall, duration of sunshine, temperature, humidity and the length of drought periods. ${ }^{3}$ Climate change has the potential to affect water quality by increasing the number of low-quality water sources and increasing the number of diffuse-source pollutant loads through heavy precipitation. Therefore, the global socio-economy will be profoundly affected by climate change such as natural hazards like flood disasters, which cause tremendous damage of infrastructure in affected areas. ${ }^{4}$ Exploitation of water resources for agriculture and industries has greatly benefited humanity. However, if "business as usual" trends remain, the cost of over exploitation will exceed the benefits, eventually resulting in uncertainty of water availability. ${ }^{5}$

Anthropogenic activities have led to modification of the natural water balance, thus affecting water supply with ultimate implications on food security. ${ }^{5,6}$ As the global human population escalates, groundwater resource is increasingly becoming an alternative to surface water. ${ }^{7}$ However, groundwater quality is characterised by its geochemical composition. ${ }^{8}$ Therefore, monitoring work is essential in determining the factors that influence its quality and quantity, whether geogenic or anthropogenic.

In this paper, the application of hydrogen, oxygen, carbon, strontium, sulphur, nitrogen and boron stable isotopes in hydrology, hydrogeology, palaeoclimatology, palaeohydrology and disaster risk management are discussed.

\section{APPROACHES OF STABLE ISOTOPES STUDIES IN THE ENVIRONMENT}

Applications of isotopes in hydrology can be separated into three different approaches depending on their respective characteristics: ${ }^{9}$

1. Tracers for stable and radioactive isotopes

2. Observing differences during the transition of the compounds as isotopes undergo isotope fractionation

3. Through the decaying of radioactive isotopes 


\subsection{Tracers}

The application of tracers in hydrology is a technique that could provide information about direction, velocity and potential contaminants in water system, coupled with hydrogeological data such as hydraulic conductivity, porosity, dispersivity and other parameters. ${ }^{10}$ Isotopes of an element are chemically similar but differences in their respective masses make them efficient tracers in a hydrological system such as a river, lake or aquifer. ${ }^{11}$ Stable and radioactive tracers have been utilised extensively in hydrological studies for the identification of underlying processes which affect the chemical and physical behaviour of elements and compounds in the natural environment. ${ }^{12,13}$

There are two fundamental techniques in isotope hydrogeology studies: first, isotopes can be artificially injected into the subsurface environment and then be utilised as tracers for water and/or solute movements; and second, isotope investigations which use existing environmental isotopes in natural systems. ${ }^{12,14}$ Natural isotopes within the system are recognised as tracers. Such an advantage helps researchers to have a better understanding on ecosystem biogeochemistry. ${ }^{13}$ Environmental isotopic fingerprints within the biogeochemical cycles are very important in reconnaissance study of environmental impact assessment. ${ }^{15,16}$

Among the advantages of utilising stable isotope elements of hydrogen and oxygen in isotope hydrogeology studies are:

1. Hydrogen and oxygen isotopes are compositions of water molecules and best approximate the characteristic of water

2. Unique hydrogen and oxygen isotopic signatures can be differentiated from water in various environments due to related isotopic fractionation effects

3. Isotope compositions in water are conservative and are hardly affected by water-rock reaction under normal temperatures ${ }^{17}$

The isotope hydrology approach is becoming more relevant to current hydrological studies. Stable isotopes of hydrogen and oxygen are useful tracers in determining the origin of groundwater with additional parameters such as temperature, stable isotopic compositions and electrical conductivity (EC) of river water. ${ }^{18,19}$ In the case of groundwater interaction investigation, combination of $\delta^{18} \mathrm{O}$ and $\delta^{2} \mathrm{H}$ tracers with piezometric surface monitoring is critical especially for effective salinity remediation strategies. ${ }^{20,21}$ Other environmental tracers can be used to develop data on hydrological histories. ${ }^{12}$ 


\subsection{Fractionation}

Geochemical or hydrological processes in the systems can be investigated by characterising the stable isotope fractionation effect. ${ }^{9}$ Stable isotope composition of water changes only through mixing, and well-known fractionation processes during evaporation and condensation. Such understanding can be exploited to identify different air and water masses that contribute to precipitation..$^{22}$ The hydrological cycle is related to the fractionation concerning water and vapour, and this phenomenon is essential in the partitioning of oxygen-18 $\left({ }^{18} \mathrm{O}\right)$ and deuterium $\left({ }^{2} \mathrm{H}\right)$ between various reservoirs (ocean, vapour, rain, runoff, groundwater, snow and ice).$^{8,23}$ Three mechanisms leading to isotopic fractionation are equilibrium, kinetic and nuclear spin. ${ }^{22}$ Furthermore, temperature plays an important role in isotope fractionation which can be associated with hydrological applications through seasonal, altitude and rainfall amount variations in tropics and subtropics (often combined with evaporation processes) ${ }^{8,24}$ Temperature conditions during rainfall or precipitation can affect stable isotope ratios. Hence, factors such as seasonal variation, latitude and altitude can change the composition of stable isotopes within precipitation. ${ }^{18,25}$ Therefore, temperature is the dominant controlling factor in isotopic composition. ${ }^{8}$

\subsection{Radioactive Decay}

Radioactive decay can also be applied in hydrology studies. This process in certain conditions could provide information regarding age determination of water resources. ${ }^{9}$ Multi-isotope techniques involving age indicators of water isotopes and isotopic composition of the dissolved constituents have been applied in determining the salinity sources and evaluating the recharge regimes and flow rates of groundwater ${ }^{26}$ Radiocarbon in dissolved organic carbon $\left({ }_{\mathrm{DO}}{ }^{14} \mathrm{C}\right)$ and helium $(\mathrm{He})$ have been established as important groundwater age indicators. ${ }^{27}$ Groundwater age is an important indicator of groundwater quality and renewal. ${ }^{28}$ In fact, it is useful in understanding the mixing mechanism of older and younger water after infiltration. . $^{29,30}$

\section{APPLICATIONS OF STABLE ISOTOPES TECHNIQUES IN THE ENVIRONMENT}

Stable isotopes of hydrogen $\left({ }^{1} \mathrm{H},{ }^{2} \mathrm{H}\right)$ and oxygen $\left({ }^{16} \mathrm{O},{ }^{17} \mathrm{O},{ }^{18} \mathrm{O}\right)$ have been extensively used for development of conceptual models, characterisation of the hydrological system, understanding the evolution of water quality, discovering origins of water, groundwater residence time and palaeohydrology research. Use of isotopes in hydrological studies have been beneficial in solving a large number 
of hydrological problems related to agriculture, industry habitation and others. ${ }^{31}$ Application of stable isotopes in hydrological studies are presented in Figure 1 and Table 1.

The fundamental principles of stable isotopes are useful for the understanding of human-hydrological systems, interconnection of climate-biology-hydrology system, paleoecohydrology and palaeoclimate systems. ${ }^{1,13,15,32-45}$ In this paper, our review focuses on hydrology, paleoecohydrology, paleoclimate and the potential application of stable isotope fundamentals in disaster risk management studies.

\subsection{Hydrology}

Fundamentally, environmental isotopes in hydrogeology and hydrology studies are focused on aspects of origin, groundwater dating and systematic patterns of isotopic composition of global precipitation. ${ }^{46-48}$ Stable isotopes (hydrogen- ${ }^{1} \mathrm{H}-{ }^{2} \mathrm{H}$, carbon- ${ }^{-12} \mathrm{C}-{ }^{13} \mathrm{C}$, nitrogen $-{ }^{14} \mathrm{~N}-{ }^{15} \mathrm{~N}$, oxygen $-{ }^{16} \mathrm{O}-{ }^{18} \mathrm{O}$, sulphur- ${ }^{32} \mathrm{~S}-{ }^{34} \mathrm{~S}$ and strontium${ }^{86} \mathrm{Sr}-{ }^{88} \mathrm{Sr}$ ) are naturally occurring elements and are considered as unique elements as they can be integrated into water molecules with minimal effect of the retardation process and with less significance to the movement of dissolved constituents. ${ }^{14}$ Such characteristics lead to the extension of physical and geochemical studies of groundwater-surface water interaction such as, determining the composition of the isotopes and chemicals of groundwater as represented by the components of rock mineralogy in the aquifer, determining the recharge area and determining the origin of the groundwater. ${ }^{9}$

To date, fundamental work still continues with wide applications of ${ }^{2} \mathrm{H}$ and ${ }^{18} \mathrm{O}$ in understanding the origin of water. ${ }^{15,49}$ Besides ${ }^{2} \mathrm{H}$ and ${ }^{18} \mathrm{O}$, other stable isotopes have their own application in watersheds studies; ${ }^{13} \mathrm{C}$ for groundwater dating, $15 \mathrm{~N}$, boron $\left({ }^{11} \mathrm{~B}\right)$ and chloride $\left({ }^{35} \mathrm{Cl}\right)$ for source of pollution, ${ }^{34} \mathrm{~S}$ for the origin of salinity and ${ }^{87} \mathrm{Sr}$ for water provenance. ${ }^{49} \mathrm{In}$ addition, $\mathrm{Cl}$ had been identified as one of the most available elements in seaweed apart from phosphorus and iodine.$^{50}$ Potentially, ${ }^{35} \mathrm{Cl}$ can be used to identify the source of $\mathrm{Cl}$ in seaweed and hypothetically, understanding the source of pollution (point source and non-point source) will be helpful in complementing current risk assessment studies.

The fundamental effects of precipitation altitude introduced are useful in identifying recharge area. ${ }^{51,52}$ The recharge of groundwater may occur during the cooler climate and in turn is lighter in its effects on its isotopic composition. Furthermore, the activity of water recharge which occurs at different locations corresponds to different systems of groundwater flow. ${ }^{29}$ The isotopic composition of delta oxygen-18 $\left(\delta^{18} \mathrm{O}\right)$ and delta deuterium $(\delta \mathrm{D})$ in natural waters are influenced by the temperature which affects evaporation and condensation processes, and which in 
turn are reflected through the changes of latitude and altitude of the geographic variations. ${ }^{53}$ Such an understanding has led to modern mean annual $\delta^{18} \mathrm{O}$ mapping for river water and precipitation in the United States where stable isotopic composition of waters at different latitude and elevation appeared as primary indicators. Precipitation form is dependent on the elevation. ${ }^{54}$ For example, during the cold season precipitation forms at very high elevations would decrease due to deficiency of water vapours. ${ }^{55}$ In other words, $\delta^{18} \mathrm{O}$ value would become negative (depleted) as the precipitation form at higher latitude. ${ }^{24}$ In terms of elevation, it is also known as altitude effect where at higher altitude, the average temperature is lower, resulting in isotopically deplete precipitation. For example, the depletion of $\delta^{18} \mathrm{O}$ would vary between $-0.15 \%$ and $-0.5 \%$, with increase in $100 \mathrm{~m}$ elevation.

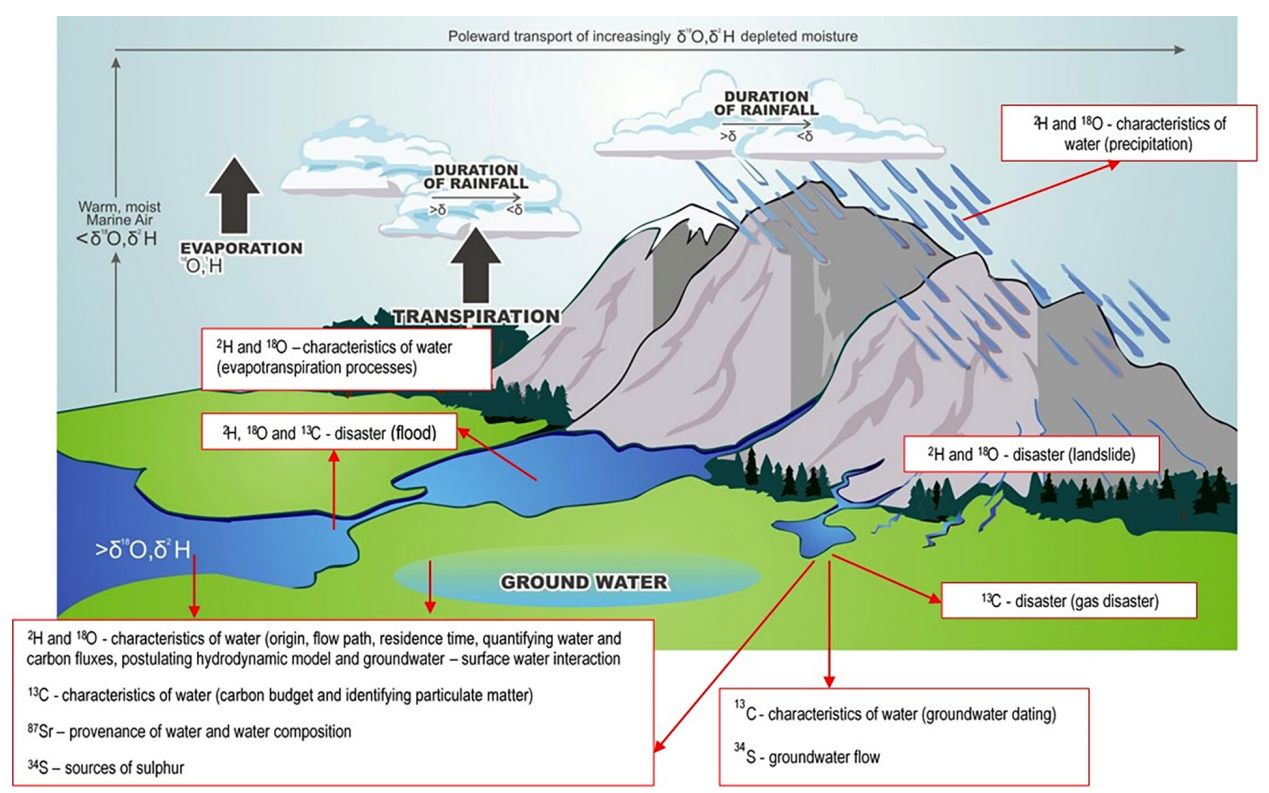

Figure 1: Application of stable isotopes in hydrological studies.

Moreover, the application of stable isotopes is not just restricted to understanding of the natural hydrological cycle. For instance, measurements of ${ }^{18} \mathrm{O}$ and ${ }^{2} \mathrm{H}$ content of rainwater collected in refuse lysimeters filled with household refuse and sewage sludge under different conditions have been done. ${ }^{56}$ The relationship of $\delta \mathrm{D}-\delta^{18} \mathrm{O}$ in the water samples has been assessed and isotopic effects caused by evaporation and biochemical reactions at initial levels could be determined from the different lysimeters with different conditions (aerobic/anaerobic, compaction, layering). In fact, to isolate sources in groundwater studies, data from hydrochemistry should be combined with the isotopic data to obtain better results. ${ }^{29}$ 
Table 1: Area of studies of stable isotopes in hydrological studies.

\begin{tabular}{|c|c|c|}
\hline Isotope & Area of study & References \\
\hline \multirow[t]{3}{*}{${ }^{2} \mathrm{H}$ and ${ }^{18} \mathrm{O}$} & $\begin{array}{l}\text { Characteristics of water (origin, flow path, residence } \\
\text { time, quantifying water and carbon fluxes, precipitation, } \\
\text { postulating hydrodynamic model, evapotranspiration } \\
\text { processes and groundwater-surface water interaction) }\end{array}$ & $\begin{array}{l}15,20,21,33,34,36 \\
37,52,53,56-71 \\
73-76\end{array}$ \\
\hline & Palaeoclimate and palaeohydrology & $38,77-87$ \\
\hline & Disaster (landslide and flood) & 88,89 \\
\hline \multirow[t]{3}{*}{${ }^{13} \mathrm{C}$} & $\begin{array}{l}\text { Characteristics of water (carbon budget, groundwater } \\
\text { dating; identifying particulate matter) }\end{array}$ & $15,39,49,84,90-92$ \\
\hline & Palaeoclimate and palaeohydrology & $78,80,81,87,93$ \\
\hline & Disaster (gas disaster) & 94 \\
\hline \multirow[t]{2}{*}{${ }^{87} \mathrm{Sr}$} & Provenance of water, water composition & $49,95,96$ \\
\hline & Palaeoclimate and palaeohydrology & 45,97 \\
\hline${ }^{34} \mathrm{~S}$ & Sources of sulphur and groundwater flow & $26,57,98$ \\
\hline${ }^{15} \mathrm{~N}$ & Sources of pollution and identifying particulate matter & $39,49,57$ \\
\hline${ }^{11} \mathrm{~B}$ & Sources of pollution & 26,49 \\
\hline
\end{tabular}

Stable isotopes of oxygen and deuterium have been utilised in understanding the characteristics (origin, flow paths and residence times) of a hydrological system, quantifying water and carbon fluxes, understanding groundwater systems, postulating hydrodynamic models and evapotranspiration processes, complemented by the application of Geographical Information System (GIS). ${ }^{15,33-37,57-62,64-74,76}$

\section{PALAEOCLIMATE AND PALAEOHYDROLOGY}

The total hydrologic cycle will be influenced by global climatic change. ${ }^{99}$ It will begin with the oceanic source region, then the atmospheric pathway and its water balance, followed by the process at land, ecosphere or atmospheric interface where the recharge flux and the surface runoff is determined and lastly the land area water balance. Palaeoclimatology studies are associated with changes of climate throughout the entire period of the earth, from the neogene to the quaternary period. ${ }^{38,39,42,43,84,86} \mathrm{In}$ this paper, more attention will be given to the quaternary period (Pleistocene and Holocene series). Stable isotopes are a good tool for investigating paleoclimatology due to its relation to meteorological parameters which enable further investigation on climatic conditions. ${ }^{42}$

Stable isotope variations in regional precipitation and palaeoclimatic changes on the Qinghai-Tibet Plateau have been determined using the combination of isotope 
compositions and the activity of $\mathrm{H}_{2} \mathrm{O}$ fluid inclusions in primary halite for the past 50,000 years. ${ }^{38} \delta^{18} \mathrm{O}$ and $\delta \mathrm{D}$ were analysed from a depth of more than $4,800 \mathrm{~m}$ and width-integrated stream samples from 391 selected sites were used in creating baseline data for other isotope hydrological studies, which will be useful in studies of regional palaeoclimate and palaeohydrology.

Climate changes of peatlands in the Holocene period have been investigated..$^{84,86}$ Stable water isotope compositions from the spring water emanating around the peat deposit were determined through an inverse relationship between electrical conductivity and isotopic composition, suggesting that precipitation was under colder and drier conditions. From analysis of nine years data collection of stable isotopes ratio of precipitation $\left(\delta^{18} \mathrm{O}\right.$ and $\left.\delta \mathrm{D}\right)$, it is notable that $\delta^{18} \mathrm{O}$ values are more sensitive compared to $\delta \mathrm{D}$ values in indicating the extremities in weather. ${ }^{43} \mathrm{In}$ studying the hydrology-mediated differential response of carbon accumulation due to late Holocene climate change in peatlands, stable water isotopes were measured temporally to understand cycling and recharge trends of peatland hydrology. ${ }^{86}$

Application of oxygen isotopes $\left(\delta^{18} \mathrm{O}\right)$ is instrumental in palaeoclimatology and palaeohydrology research. ${ }^{77-83,85,87,92,93}$ Coupling the isotopic data with other parameters like air temperature provides understanding of significant past events in the studied system, i.e., tropical cyclones. ${ }^{77}$ In another study, the $\delta^{18} \mathrm{O}$ of biogenic and endogenic carbonates from 24 lake basins were determined to reconstruct multi-millennial-scale trends for assessment of spatial coherency of Late Quaternary climate change across the circum-Mediterranean region. ${ }^{82}$ Information from the inference of isotopic patterns in watersheds provides useful information about the implications of anthropogenic activities. Hydroecological evolution of the Athabasca Delta over the 20th century reflected that the Athabasca River flow regime was strongly affected by an engineered meander cut-off on the Athabasca river as well as climate warming, with the naturally declining river discharge contributing to the directional change. ${ }^{83}$

The carbon isotope $\left(\delta^{13} \mathrm{C}\right)$ also plays an important role in palaeoclimatology and palaeohydrology studies, especially on organic matters and minerals $\left(\delta^{13} \mathrm{C}_{\text {org }}\right.$ and $\delta^{13} \mathrm{C}_{\text {carb }}$ ) related to the sediment depth and time..$^{78,80,81,87,92}$ The combination of $\delta^{18} \mathrm{O}$ and $\delta^{13} \mathrm{C}$ measurements in lake sediments can provide details regarding salinity and productivity in a lake, which in turn reflect lake-level and climatic changes. ${ }^{80}$ In estuaries, the use of paleolimnology always seeks to determine environmental changes occurring over time. ${ }^{100}$ In terms of salinity studies, the combined hydrogen isotopic composition of the preserved alkenones and n-alkanes provide information on significant changes in both $\delta \mathrm{D}_{\text {water }}$ and $\delta \mathrm{D}_{\text {precipitation }}$ of the Black Sea area during the Messinian Salinity Crisis. ${ }^{93}$ 
The study of $\delta^{18} \mathrm{O}$ and $\delta^{13} \mathrm{C}$ in lacustrine authigenic calcites provide a useful indicator of past climatic change through the Holocene period, with a high degree of covariance between these two stable isotopes suggesting that evaporation and exchange have controlled the hydrological balance. ${ }^{81}$ Strong $\delta^{18} \mathrm{O}-\delta^{13} \mathrm{C}$ covariance as characteristic of a closed lake have been argued. ${ }^{80}$ Oxygen and carbon stable isotopes were also analysed in understanding changes in the balance between evaporation and precipitation, determining past lake levels and identifying carbon sources in characterising late Pleistocene-early Holocene climate conditions and water levels of a lake. ${ }^{87}$

Strontium $\left(\delta^{87} \mathrm{Sr}\right)$ is another stable isotope that is relevant in the studies of palaeoclimate and palaeohydrology. Through the measurements of strontium concentrations and isotopic ratios in natural waters and carbonate sediments of lakes and rivers of the Altiplano, changes of $\delta^{87} \mathrm{Sr}$ observed provided better understanding of the palaeohydrology and palaeoclimatic history of the central Andes..$^{97}$ In addition, application of strontium isotope as a tracer for water habitat and in fossil specimens were applied in investigating palaeohydrology of a palaeolake during the early-middle Pleistocene period. ${ }^{45}$

\subsection{Other Applications for Environmental Research}

C3 plant-derived material appear as the primary source of carbon, with dissolved inorganic carbon $\left(\delta^{13} \mathrm{C}_{\mathrm{DIC}}\right)$ values enriched in ${ }^{13} \mathrm{C}$ relative to that of the $\mathrm{C} 3$ source retrieved from isotopic constraints on the aquatic carbon budget in Langat watershed, Malaysia. ${ }^{73}$ It has also been suggested that human-induced perturbations (anthropogenic-derived organic carbon input from sewage treatment plants and landfill sites) to riverine carbon cycling should be put into consideration in the future studies of urbanised watersheds.

Other applications of $\delta^{13} \mathrm{C}$ are source identification of riverine particulate organic matter (POM). ${ }^{39,82,90} \mathrm{Using} \delta^{13} \mathrm{C}, \delta^{15} \mathrm{~N}$ and $\mathrm{C}: \mathrm{N}$ ratios, sources of POM in major river systems can be determined. Low $\delta^{13} \mathrm{C}$ and $\mathrm{C}: \mathrm{N}$ values suggested the occurrence of plankton blooms in spring and summer. ${ }^{39}$ For DIC, $\delta^{13} \mathrm{C}$ demonstrates the role of atmospheric exchange and organic carbon oxidation in the isotopic signature of DIC. ${ }^{90}$

Stable isotopes of $\mathrm{Sr}$ and $\mathrm{S}$ are also instrumental in hydrology research. ${ }^{87} \mathrm{Sr}$ has been commonly applied in studying the provenance of water. ${ }^{49}$ It has also been used as a tracer to determine the water rock interaction. ${ }^{101}$ Stable isotopes of strontium $\left({ }^{87} \mathrm{Sr}\right)$ have been measured to determine the origin of water, and complemented with hydrochemistry data are helpful in describing the main sources of the water composition. ${ }^{95}$ 
In this case, higher $\delta^{87} \mathrm{Sr}$ values indicated that the sources originated from older terrains while lower $\delta^{87} \mathrm{Sr}$ values specified that the sources are from relatively younger terrains. In another study, $\mathrm{Sr}$ isotopes have been utilised in developing an isotope distribution map that will be the source for provenance applications, archaeological migration studies, groundwater-surface water-seawater interaction/ contamination monitoring and potential use for the agricultural and food sector. ${ }^{96}$ Moreover, the ${ }^{87} \mathrm{Sr} r{ }^{86} \mathrm{Sr}$ system is a powerful tool for constraining plate tectonic processes and their influence on atmospheric $\mathrm{CO}_{2} \cdot{ }^{102}$

Stable isotopes of $\delta^{34} \mathrm{~S}$ have been applied to understand sources of sulphur in stream water which specified the primary sources of $\mathrm{SO}_{4}{ }^{2-} \cdot{ }^{98}$ Different tracers provide different information on studied watersheds. Stable isotopes of water with ${ }^{13} \mathrm{C},{ }^{15} \mathrm{~N},{ }^{34} \mathrm{~S}$ and ${ }^{87} \mathrm{Sr}$ and some other radioactive isotopes have been selected in investigating the complexity of groundwater flow of a wetland. ${ }^{57}$ The function of using these isotopes is to learn about the provenance, flow paths and residence times or ages of the wetland. ${ }^{57}$ Stable isotope compositions of $\delta^{18} \mathrm{O}, \delta^{2} \mathrm{H}, \delta^{11} \mathrm{~B}, \delta^{13} \mathrm{C}$ and $\delta^{87} \mathrm{Sr}$ together with radioactive isotopes were investigated to understand the origin and processes of groundwater contamination in the studied aquifer. ${ }^{26}$

Stable isotopes $\left(\delta^{18} \mathrm{O}, \delta \mathrm{D}, \delta^{13} \mathrm{C}\right.$ and $\left.\delta^{3} \mathrm{He}\right)$ have coupled with radioactive isotopes (tritium- ${ }^{3} \mathrm{H},{ }^{14} \mathrm{C}$ and ${ }^{4} \mathrm{He}$ ) and hydrogeochemical tools in studying flow regimes and their time scales, to determine recharge conditions, and to describe the regional-scale hydrogeochemical evolution of groundwater. ${ }^{103}$ Stable water isotopes with radioactive isotopes of ${ }^{3} \mathrm{H}$ and ${ }^{14} \mathrm{C}$ have been applied in explaining the hydrochemical characteristics of river water, hydrochemistry of groundwater, stable isotope ratios in river water, recharge of groundwater, recharge origin of springs, spatial variation in the d-excess value as well as ${ }^{3} \mathrm{H}$ contents and ${ }^{14} \mathrm{C}$ of river water, groundwater and spring water. ${ }^{23,31,91}$ The combination of stable water isotopes with radioactive isotopes of tritium and ${ }^{14} \mathrm{C}$, as well as chemical and noble gases tracers were applied in understanding the groundwater-surface water interactions that explained about the infiltration rates, episodic recharge and origin of the older groundwater source. ${ }^{104}{ }^{3} \mathrm{H}$ is also effective in estimating the flushing time of large river basins. This evidence is important for the conservative contamination of watersheds. ${ }^{30}$

\subsection{Disaster Risk Management Studies}

Disaster risk management for natural hazards can be considered a new venture of stable isotopes application in watersheds research. It is critical to identify factors that contribute to natural disasters within a catchment area. Deforestation activities have weakened the hydrological cycle due to the changes in the land surface. 
Increase in deforestation activity would cause the erosion process to be generated and thus, river sedimentation and increase risk of natural disaster. ${ }^{16}$ Several studies will be presented to highlight its importance. Figure 2 shows the locations of several study highlighted in disaster risk management.

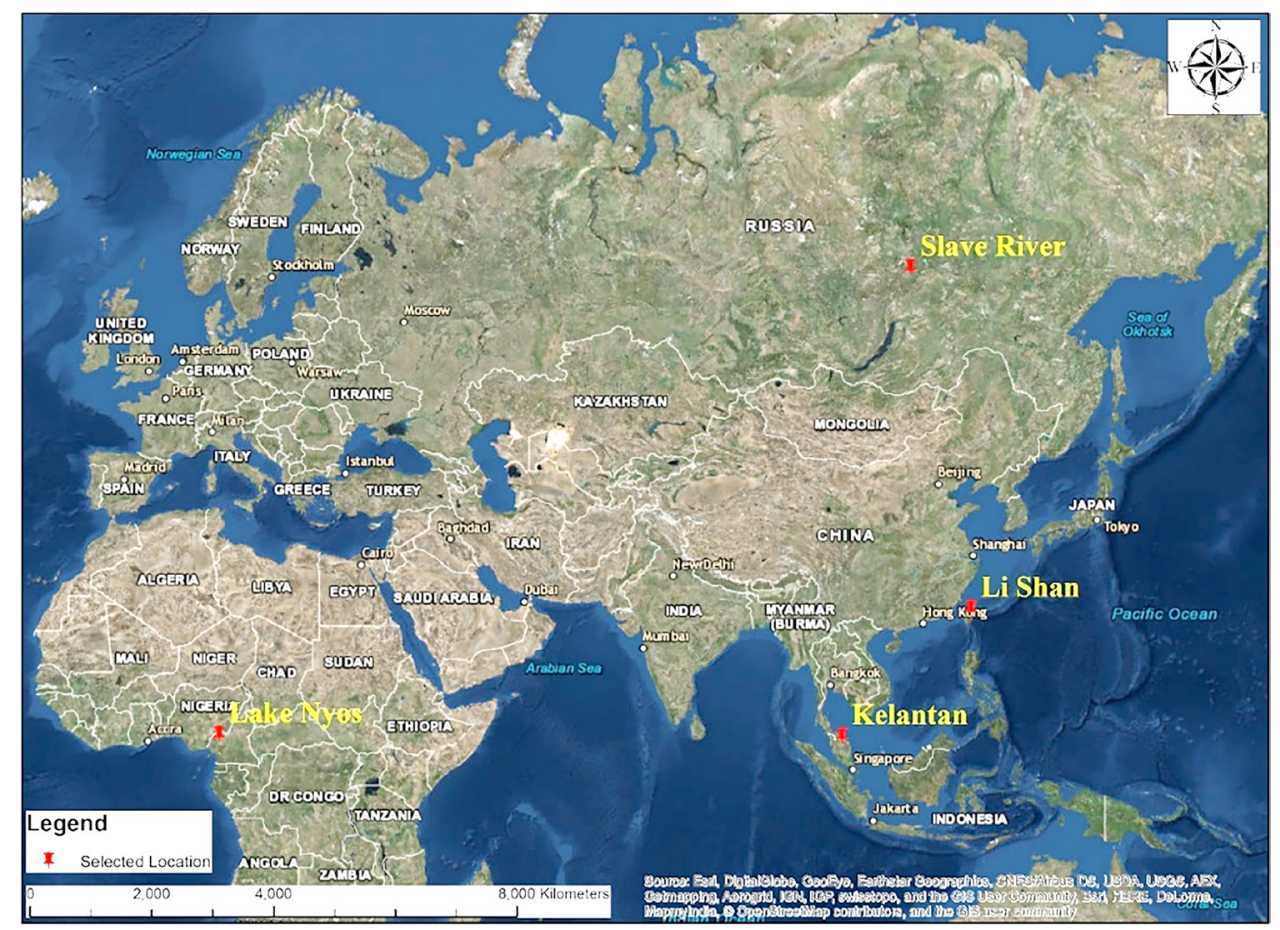

Figure 2: Location for several study highlighted (produced with ArcGIS 10.3).

\subsubsection{Cameroonian crater lake}

In August 1986, the Lake Nyos tragedy (located in the region of volcanic activity) took the life of approximately 1700 people. ${ }^{105,106}$ Lake Nyos is located in the Cameroon Volcanic Zone. It was due to the sudden release of $\mathrm{CO}_{2}$ gas from the bottom of Lake Nyos that was conveyed by groundwater. The $\mathrm{CO}_{2}$ gas released was localised in the form of a $120 \mathrm{~m}$ high plume that spread in the region of $25 \mathrm{~km} .{ }^{105}$ Stable isotope ratios of total dissolved carbon $\left(\delta^{13} \mathrm{C}\right)$ have been investigated for three Cameroonian crater lakes (Nyos, Monoun and Wum) to investigate the cause of the Nyos gas disaster in $1986 .{ }^{94}$ Results ( $-3 \%$ o for Nyos and $-5.5 \%$ for Monoun) showed the origin of the gases linked with the disaster as these values indicate the $\delta^{13} \mathrm{C}$ of carbon in magma from mantel beneath the Lake Nyos. 


\subsubsection{Li-Shan area (central Taiwan)}

Li Shan area is situated less than $3 \mathrm{~km}$ from the Li-Shan fault. ${ }^{107}$ Compositions of oxygen and hydrogen stable isotopes coupled with tritium have been analysed to identify the hydrologic factors that contributed to a severe landslide in the Li-Shan area, central Taiwan. ${ }^{88}$ From the analysis of $\delta \mathrm{D}$ versus $\delta^{18} \mathrm{O}$ of slope groundwater samples, it was concluded that pond water from He-Huan-Xi creek and precipitation are the two main sources for slope groundwater in the Li-Shan landslide area.

\subsubsection{Slave river delta}

During the spring break-up period, the melting of the winter snowpack is critical in influencing the Slave River discharge. ${ }^{108}$ Figure 4 shows the map of Slave River located in Canada. Stable water isotope tracers, combined with total inorganic suspended sediment (TSS) concentrations quantified from lake water samples collected shortly after the spring melt, were analysed in order to distinguish the spatial and temporal patterns of spring break-up flooding in the Slave River Delta. ${ }^{89}$ Isotopically-depleted $\delta^{18} \mathrm{O}$ and $\delta \mathrm{D}$ signatures and high TSS concentrations characterised the flooded lakes.

\subsubsection{Kelantan river basin}

Dominant water flux through transpiration reflects the significant role of vegetation in regulating the regional water cycle. ${ }^{15}$ Hence, negligence of the role of forests as a major hydrologic component may undermine the ecosystem capacity to regulate water balance in a tropical region. If this is so, was deforestation the main culprit for the destructive 2014 floods in Kelantan? Initially, datasets of Precipitation and Water Level for the main rivers in the Kelantan catchment, i.e., Sungai Lebir, Sungai Galas and Sungai Kelantan, were observed from 17 December 2014 to 6 January 2015. Figure 3 shows the map of Kelantan River Basin. The dataset was retrieved from the state government official portal (ebanjir.kelantan.gov.my). Results showed that unusually high amount of rainfall co-varies with the water level in the three rivers, reflecting the high intensity of the monsoon which is the main driver of water input (rainfall) to the Kelantan watershed. Delta ${ }^{18} \mathrm{O}$ and $\delta^{2} \mathrm{H}$ of precipitation collected nationwide were analysed to improve understanding of stable isotope systems in Malaysia, essential for climate-hydrology interpretation of modern stable isotopic fingerprints of $\delta^{18} \mathrm{O}$ and $\delta^{2} \mathrm{H}$ preserved in meteoric waters. ${ }^{109}$ Moreover, the Rayleigh distillation process occurs along the trajectory of air mass resulting in partitioning of heavier isotopes $\left({ }^{18} \mathrm{O}\right.$ and deuterium) into the rain. Isotopically enriched rain forms in the early monsoon, and falling from a diminishing vapour mass the residual vapour eventually becomes isotopically 
depleted. The systematic rainout process continues with more moisture supply during the peak monsoon, again resulting in enriched precipitation. However, this was not the case for 2014, as the system received more moisture supply as demonstrated in the isotopic composition of $\delta^{18} \mathrm{O}$ and $\delta^{2} \mathrm{H}$ within precipitation. ${ }^{15}$ Understanding the moisture sources is critical to climate-hydrology studies. Thus, stable isotope monitoring facilities should be in serious consideration for an extensive national environmental monitoring programme, which will be able to provide comprehensive support to the development of a flood forensics and management framework as a complement to the Disaster Risk Management for Sustainable Development (DRM-SD) agenda.

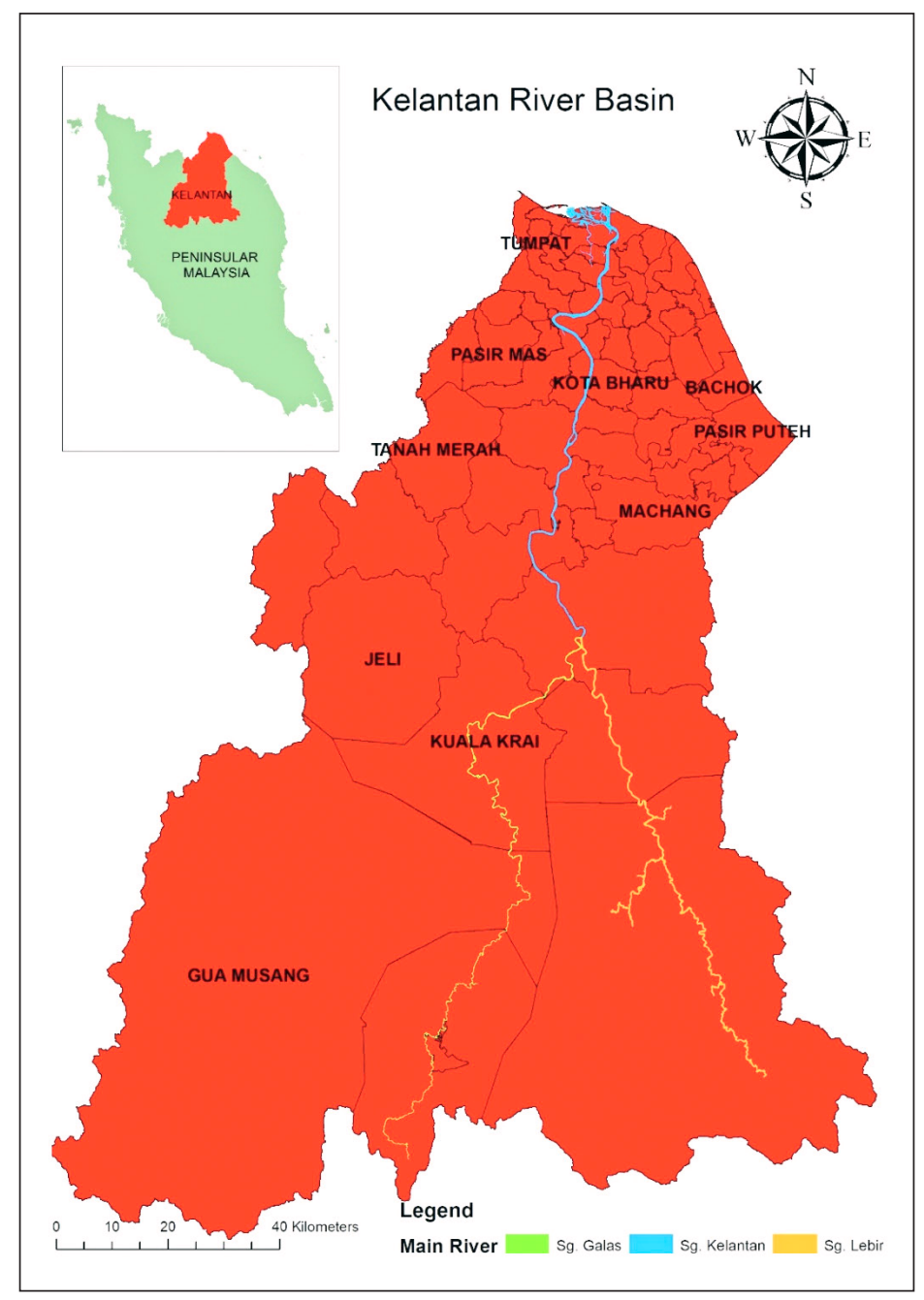

Figure 3: Map of Kelantan river basin (produced with ArcGIS 10.3). 
Application of stable isotopes in hydrological studies demonstrated its significance, particularly in characterising water resources, palaeoclimate and palaeohydrology which complement disaster risk management of watersheds framework. For example, the study in coupling of water and carbon fluxes via the terrestrial biosphere and its significance to the earth's climate system. ${ }^{35}$ They had determined that with the variation of water inputs by rain, the estimates of transpiration show the same as net primary productivity, suggesting the terrestrial water and carbon cycle naturally coupled through biosphere with in small-scale measurements. Others include the characteristics of chemistry and stable isotopes in groundwater of Chaobai and Yongding River basin, North China Plain to understand the groundwater flow system. ${ }^{66}$ Table 2 shows historical applications of stable isotopes in hydrological studies.

Table 2: Chronological order of applications of stable isotopes in hydrological studies.

\begin{tabular}{|c|c|c|}
\hline Year & Area of study & References \\
\hline 1935 & The relative atomic weight of oxygen in air and water & 46 \\
\hline 1957 & Groundwater dating through the application of radiocarbon & 47 \\
\hline 1961 & Systematic pattern of isotopic composition of global precipitation & 48 \\
\hline 1964 & Fundamental of precipitation altitude effect & 51 \\
\hline 1964 & Stable isotope in precipitation & 51 \\
\hline 1965 & Deuterium and oxygen-18 variation in the ocean and marine atmosphere & 110 \\
\hline 1975 & Isotope techniques in groundwater hydrology & 15 \\
\hline 1977 & $\begin{array}{l}\text { Compilation of stable isotope fractionation factors of geochemical } \\
\text { interest }\end{array}$ & 111 \\
\hline 1989 & $\begin{array}{l}\text { Using } \delta^{13} \mathrm{C} \text { measurements in understanding the cause of Nyos gas } \\
\text { disaster }\end{array}$ & 94 \\
\hline 1993 & $\begin{array}{l}\text { Estimating evaporation using stable isotope: Quantitative results and } \\
\text { sensitivity analysis for two catchments in northern Canada }\end{array}$ & 112 \\
\hline 1995 & $\begin{array}{l}\text { Measurements of }{ }^{18} \mathrm{O} \text { and } \mathrm{D} \text { content of rainwater collected in refuse } \\
\text { lysimeters }\end{array}$ & 56 \\
\hline 1995 & $\begin{array}{l}\text { Stable isotopes of lake and fluid inclusion brines, Dabusun Lake, } \\
\text { Qaidam basin, western China: Hydrology and paleoclimatology in arid } \\
\text { environments }\end{array}$ & 38 \\
\hline 1995 & Analysis of sulphur isotopes in suggesting changes in surficial materials & 98 \\
\hline 1996 & Identifying recharge area & 52 \\
\hline 1998 & $\begin{array}{l}\text { Study of stable isotopic ratio of precipitation from tropical cyclones in } \\
\text { characterising hydrology and palaeoclimatology }\end{array}$ & 77 \\
\hline 1998 & Stable isotope composition of precipitation over Southeast Asia & 113 \\
\hline
\end{tabular}


Table 2: (Continued)

\begin{tabular}{|c|c|c|}
\hline Year & Area of study & References \\
\hline 2000 & $\begin{array}{l}\text { Measurement of naturally-occurring isotopes in the hydrosphere } \\
\text { providing indication of provenance, flow paths and residence times of } \\
\text { wetland groundwater flow systems }\end{array}$ & 57 \\
\hline 2000 & Quantification of water and carbon fluxes & 33 \\
\hline 2002 & $\begin{array}{l}\text { Regional water balance trends an evaporation-transpiration partitioning } \\
\text { from a stable isotope survey of lakes in northern Canada }\end{array}$ & 114 \\
\hline 2003 & $\begin{array}{l}\text { Measurements of strontium concentrations and isotopic ratios to } \\
\text { improve hydrology and palaeohydrology mass balances to understand } \\
\text { palaeoclimatic history }\end{array}$ & 97 \\
\hline 2003 & $\begin{array}{l}\text { Water and carbon cycles in the Mississippi River basin: Potential } \\
\text { implications for the Northern Hemisphere residual terrestrial sink }\end{array}$ & 34 \\
\hline 2004 & Study of last interglaciation climate and hydrology using $\delta^{18} \mathrm{O}$ and $\delta^{13} \mathrm{C}$ & 81 \\
\hline 2004 & $\begin{array}{l}\text { Using stable water isotopes to evaluate basin-scale simulations of } \\
\text { surface water budgets }\end{array}$ & 115 \\
\hline 2004 & $\begin{array}{l}\text { The Piracicaba River basin: Isotope hydrology of a tropical river basin } \\
\text { under anthropogenic stress }\end{array}$ & 116 \\
\hline 2005 & Postulating hydrodynamic model & 60 \\
\hline 2005 & $\begin{array}{l}\text { Measurements of }{ }^{18} \mathrm{O} \text { and } \mathrm{D} \text { to determine possible evapotranspiration } \\
\text { processes }\end{array}$ & 59 \\
\hline 2005 & $\begin{array}{l}\text { Groundwater-surface water interactions were studied using piezometric } \\
\text { surface monitoring and environmental tracers }\end{array}$ & 20 \\
\hline 2005 & Progress in isotope tracer hydrology in Canada & 13 \\
\hline 2006 & $\begin{array}{l}\text { Application of isotope tracers in continental scale hydroligical } \\
\text { modelling }\end{array}$ & 116 \\
\hline 2007 & Distinguishing sources of groundwater recharge using $\delta^{2} \mathrm{H}$ and $\delta^{18} \mathrm{O}$ & 61 \\
\hline 2007 & $\begin{array}{l}\text { Identifying dominant runoff sources and estimating mean residence } \\
\text { times using tracer investigations and GIS analysis }\end{array}$ & 65 \\
\hline 2007 & $\begin{array}{l}\text { Identifying possible hydrologic factors contributing to a severe } \\
\text { landslide in Li-Shan (central Taiwan) using stable water isotopes }\end{array}$ & 88 \\
\hline 2007 & $\begin{array}{l}\text { Coupling of water and carbon fluxes via the terrestrial biosphere and its } \\
\text { significance to the earth's climate system }\end{array}$ & 35 \\
\hline 2007 & $\begin{array}{l}\text { Isotope constraints on water, carbon and heat fluxes from the Northern } \\
\text { Great Plains Region of North America }\end{array}$ & 63 \\
\hline 2008 & Characteristics of chemistry and stable isotopes in groundwater & 66 \\
\hline 2008 & $\begin{array}{l}\text { Application of stable water isotopes in reconstructing spatial and } \\
\text { temporal patterns of spring break-up flooding in the Slave River Delta }\end{array}$ & 88 \\
\hline
\end{tabular}


Table 2: (Continued)

\begin{tabular}{|c|c|c|}
\hline Year & Area of study & References \\
\hline 2008 & $\begin{array}{l}\text { Water and carbon fluxes from savanna ecosystems of the Volta River } \\
\text { watershed, West Africa }\end{array}$ & 67 \\
\hline 2008 & $\begin{array}{l}\text { Net ecosystem production in the great lakes basin and its implications } \\
\text { for the north American missing carbon sink: A hydrologic and stable } \\
\text { isotope approach }\end{array}$ & 69 \\
\hline 2009 & $\begin{array}{l}\text { Investigation of peatlands climate and hydrology changes in Holocene } \\
\text { period using } \delta^{14} \mathrm{C}\end{array}$ & 84 \\
\hline 2010 & $\begin{array}{l}\text { Under-ice salinity and stable isotope distribution of Saroma-ko Lagoon, } \\
\text { Hokkaido, northern Japan }\end{array}$ & 21 \\
\hline 2011 & $\begin{array}{l}\text { Application of strontium isotopes on snail Melanopsis as a tracer for } \\
\text { water in its habitat to investigate palaeohydrology }\end{array}$ & 44 \\
\hline 2011 & $\begin{array}{l}\text { Application of stable water and carbon isotopes in watershed research: } \\
\text { Weathering, carbon cycling and water balances }\end{array}$ & 36 \\
\hline 2013 & Study of isotope constraints on the aquatic carbon budget & 73 \\
\hline 2013 & $\begin{array}{l}\text { Investigation of carbon accumulation in studying petlands climate } \\
\text { changes in late Holocene period }\end{array}$ & 86 \\
\hline 2014 & $\begin{array}{l}\text { A reconnaissance study of water and carbon flux in tropical watershed } \\
\text { of Peninsular Malaysia: Stable isotope constraints }\end{array}$ & 75 \\
\hline 2014 & $\begin{array}{l}\text { A reconnaissance study of water and carbon flux in tropical watershed } \\
\text { of Peninsular Malaysia: Stable isotope constraints }\end{array}$ & 15 \\
\hline
\end{tabular}

\section{CONCLUSION}

Water is one of the critical resources in the sustainability agenda. Yet, among all observed natural and anthropogenic adversities, water-related disasters appear as the most recurrent which hinder sustainable socio-economic development goals. ${ }^{117}$ Climate change, urban expansion, deforestation and increase in population are thought to be the main factors of water-related disasters. Considering those factors, understanding the hydrologic balance of watersheds and the impact that nature and humanity impose on regional ecosystems becomes one of the important research priorities.

The application of isotope tracers is an important tool in resolving issues related to physical hydrology and geochemistry of river basins. Application of isotope hydrology as a technique in studying the water cycle from various environments (ocean to atmosphere) and processes is becoming more common and accepted in hydrological studies. Stable isotopes of oxygen and hydrogen are part of water molecules which provide useful information in understanding the characteristics 
and history of water. Furthermore, development of new analytical techniques and approaches such as high-resolution isotope data using new laser spectroscopy technology in combination with GIS is one example of making stable isotope utilisation in watershed research more efficient.

Stable isotopes of oxygen and deuterium play an important role in providing related information in reconstructing and understanding the history of the studied hydrological system or environments. Besides these isotopes, stable carbon and strontium isotopes also contribute to palaeoclimate and palaeohydrology studies through the analysis of sediments and organic matters. Moreover, stable isotopes of carbon, strontium, sulphur and nitrogen are example of multi-isotope techniques that may be combined to provide a greater understanding of the earth system.

This paper reviews the applications of stable isotopes in hydrological studies for catchment management. Advancement in isotope research (origin, flow paths, residence times and water budget) has led to new frontiers of palaeoclimatology and palaeohydrology studies. Future applications hold promise to recognise the patterns of modern and ancient isotopic signatures in the ecosystem, provide useful information in understanding potential natural hazards, and thus complement disaster risk management of watersheds.

\section{ACKNOWLEDGEMENTS}

The authors gratefully acknowledge the financial provided from grant 304/ PTEKIND/6313266, Universiti Sains Malaysia, Pulau Pinang.

\section{REFERENCES}

1. Edmunds, W. M. (2009). Geochemistry's vital contribution to solving water resource problems. Appl. Geochem., 24(6), 1058-1073, https://doi. org/10.1016/j.apgeochem.2009.02.021.

2. Bowen, G. J. \& Good, S. P. (2015). Incorporating water isoscapes in hydrological and water resource investigations. Wiley Interdisc. Rev. Wat., 2(2), 107-119, https://doi.org/10.1002/wat2.1069.

3. Alam, M. M. et al. (2013). Agricultural vulnerability and adaptation to climatic changes in Malaysia: Review on paddy sector. Curr. World Environ., 8(1), 1-12, https://doi.org/10.12944/CWE.8.1.01.

4. Kundzewicz, Z. W. et al. (2008) The implications of projected climate change for freshwater resources and their management. Hydrol. Sci. J., 53(1), 3-10, https://doi.org/10.1623/hysj.53.1.3. 
5. Sancho, F. I. A. et al. (2011). Groundwater development effects on different scale hydrogeological systems using head, hydrochemical and isotopic data and implications for water resources management: The Selva basin (NE Spain). J. Hydrol., 403, 1-2, 83-102, https://doi.org/10.1016/j. jhydrol.2011.03.041.

6. Van Geldern, R. et al. (2014). Pleistocene paleo-groundwater as a pristine fresh water resource in southern Germany: Evidence from stable and radiogenic isotopes. Sci. Total Environ., 496, 107-115, https://doi. org/10.1016/j.scitotenv.2014.07.011.

7. Wassenaar, L. I., Athanasopoulos, P. \& Hendry, M. J. (2011). Isotope hydrology of precipitation, surface and ground waters in the Okanagan Valley, British Columbia, Canada. J. Hydrol., 411(1), 37-48, https://doi. org/10.1016/j.jhydrol.2011.09.032.

8. Clark, I. D. \& Fritz, P. (1997). Environmental isotopes in hydrology. New York: Lewis Publishers.

9. Mook, W. G. (2006). Introduction to isotope hydrology: Stable and radioactive isotopes of hydrogen, oxygen and carbon. New Yok: Taylor $\&$ Francis.

10. Davis, S. N. et al. (1980). Ground-water tracers: A short review. Groundwat., 18(1), 14-23, https://doi.org/10.1111/j.1745-6584.1980.tb03366.x.

11. Singh, B. P. \& Kumar, B. (2005). Isotopes in hydrology, hydrogeology and water resources. London: Alpha Science.

12. Evans, G. V. (1983). Tracer techniques in hydrology. Int. J. Appl. Radiat. Isot., 34(1), 451-475, https://doi.org/10.1016/B978-0-08-029158-1.500386.

13. Gibson, J. J. et al. (2005). Progress in isotope tracer hydrology in Canada. Hydrol. Proc., 19(1), 303-327, https://doi.org/10.1002/hyp.5766.

14. Fontes, J. C. \& Fritz, P. (1975). Isotope hydrology 1974: A review of the IAEA symposium on isotope techniques in groundwater hydrology. Int. J. Appl. Radiat. Isot., 26(1), 1-8, https://doi.org/10.1016/0020708X(75)90002-2.

15. Syakir, M. I. et al. (2014). A reconnaissance study of water and carbon fluxes in a tropical watershed of Peninsular Malaysia: Stable isotope constraints. Paper presented at the Proceedings of FRIEND-Water 2014, Hanoi, Vietnam, IAHS Publication 363.

16. Zafirah, N. et al. (2017). Sustainable ecosystem services framework for tropical catchment management: A review. Sustain., 9(4), 546, https://doi. org/10.3390/su9040546.

17. Peng, T. R. et al. (2010). Identification of groundwater sources of a localscale creep slope: Using environmental stable isotopes as tracers. J. Hydrol., 381(1), 151-157, https://doi.org/10.1016/j.jhydrol.2009.11.037. 
18. Delinom, R. M. \& Suriadarma, A. (2010). Groundwater flow system of Bandung basin based on hydraulic head, subsurface temperature, and stable isotopes. RISET Geol. Pertamb., 20(1), 55-68, https://doi.org/10.14203/ risetgeotam2010.v20.34.

19. Rautio, A. et al. (2015). Vulnerability of groundwater resources to interaction with river water in a boreal catchment. Hydrol. Earth Syst. Sci., 19, 3015-3032, https://doi.org/10.5194/hess-19-3015-2015.

20. Lamontagne, S., Leaney, F. W. \& Herczeg, A. L. (2005). Groundwatersurface water interactions in a large semi-arid floodplain: Implications for salinity management. Hydrol. Proc., 19(16), 3063-3080, https://doi. org/10.1002/hyp.5832.

21. Morimoto, M. et al. (2010). Under-ice salinity and stable isotope distribution of Saroma-ko Lagoon, Hokkaido, northern Japan. Hydrol. Proc., 24(7), 904-916, https://doi.org/10.1002/hyp.7532.

22. Michener, R. \& Lajtha, K. (Eds.). (2008). Stable isotopes in ecology and environmental science. New York: John Wiley \& Sons.

23. Gibson, J. J. et al. (2011). Isotopic and geochemical tracers for fingerprinting process-affected waters in the oil sands industry: A pilot study. Edmonton: School of Energy and the Environment, University of Alberta.

24. Dansgaard, W. (1964). Stable isotopes in precipitation. Tellus, 16(4), 436468, https://doi.org/10.3402/tellusa.v16i4.8993.

25. Vystavna Y., Diadin D. \& Huneau F. (2016). Describing stable water isotopes framework for the surface water, groundwater and precipitation in East Ukraine. Paper presented at the 7th International Conference on Water Resources and Environment Research, Kyoto TERRSA, Kyoto, 5-9 June.

26. Vengosh, A. et al. (2002). A multi-isotope (B, Sr, O, H, and C) and age dating $\left({ }^{3} \mathrm{H}-{ }^{3} \mathrm{He}\right.$ and $\left.{ }^{14} \mathrm{C}\right)$ study of groundwater from Salinas Valley, California: Hydrochemistry, dynamics, and contamination processes. Wat. Res. Res., 38(1), https://doi.org/10.1029/2001WR000517.

27. Nakata, K. et al. (2013). Groundwater dating using radiocarbon in fulvic acid in groundwater containing fluorescein. J. Hydr., 489, 189-200, https://doi.org/10.1016/j.jhydrol.2013.03.012.

28. Jasechko, S. (2016). Partitioning young and old groundwater with geochemical tracers. Chem. Geol., 427, 35-42, https://doi.org/10.1016/j. chemgeo.2016.02.012.

29. Hussien, B. (2010). Application of environmental isotopes technique in groundwater recharge within Mullusi carbonate aquifer-West Iraq. Iraqi J. Des. Stud., 2(2), 100-110.

30. Michel, R. (2005). Tritium in the hydrologic cycle. Isot. Water Cycle, 53-66. 
31. Srivastaza T., Rai S. P. \& Pandey G. (2015). Importance of isotopes in characterizing water. Int. J. Eng. Tech. Res., 3(11), November.

32. Bowen, G. J., Cerling, T. E. \& Ehleringer, J. R. (2007). Stable isotopes and human water resources: Signals of change. Terr. Ecol., 1, 283-300, https://doi.org/10.1016/S1936-7961(07)01018-4.

33. Telmer, K. \& Veizer, J. (2000). Isotopic constraints on the transpiration, evaporation, energy, and gross primary production budgets of a large boreal watershed: Ottawa River basin, Canada. Glob. Biogeochem. Cycl., 14(1), 149-165, https://doi.org/10.1029/1999GB900078.

34. Lee, D. \& Veizer, J. (2003). Water and carbon cycles in the Mississippi River basin: Potential implications for the Northern Hemisphere residual terrestrial sink. Glob. Biogeochem. Cycl., 17(2), https://doi. org/10.1029/2002GB001984.

35. Ferguson, P. R. \& Veizer, J. (2007). Coupling of water and carbon fluxes via the terrestrial biosphere and its significance to the Earth's climate system. J. Geophys. Res. Atmosph., 112(D24), https://doi.org/10.1029/ 2007JD008431.

36. Schulte, P. et al. (2011). Applications of stable water and carbon isotopes in watershed research: Weathering, carbon cycling, and water balances. EarthSci. Rev., 109(1), 20-31, https://doi.org/10.1016/j.earscirev.2011.07.003.

37. Jasechko, S. et al. (2013). Terrestrial water fluxes dominated by transpiration. Nature, 496(7445), 347-350, https://doi.org/10.1038/nature11983.

38. Yang, W. et al. (1995). Stable isotopes of lake and fluid inclusion brines, Dabusun Lake, Qaidam Basin, western China: Hydrology and paleoclimatology in arid environments. Palaeogeogr. Palaeoclim. Palaeoecol., 117(3-4), 279-290, https://doi.org/10.1016/0031-0182(94) 00126-S.

39. Kendall, C. \& Coplen, T. B. (2001). Distribution of oxygen-18 and deuterium in river waters across the United States. Hydrol. Proc., 15(7), 1363-1393, https://doi.org/10.1002/hyp.217.

40. Henderson, A. C., Holmes, J. A. \& Leng, M. J. (2010). Late Holocene isotope hydrology of Lake Qinghai, NE Tibetan Plateau: Effective moisture variability and atmospheric circulation changes. Quat. Sci. Rev., 29(17), 2215-2223, https://doi.org/10.1016/j.quascirev.2010.05.019.

41. Henderson, A. K. \& Shuman, B. N. (2010). Differing controls on riverand lake-water hydrogen and oxygen isotopic values in the western United States. Hydrol. Proc., 24(26), 3894-3906, https://doi.org/10.1002/ hyp. 7824.

42. Darling, W. G. (2011). The isotope hydrology of quaternary climate change. J. Hum. Evol., 60(4), 417-427, https://doi.org/10.1016/j.jhevol. 2010.05.006. 
43. Vodila, G. et al. (2011). A 9-year record of stable isotope ratios of precipitation in Eastern Hungary: Implications on isotope hydrology and regional palaeoclimatology. J. Hydrol., 400(1), 144-153, https://doi. org/10.1016/j.jhydrol.2011.01.030.

44. Van Geldern, R. et al. (2014). Pleistocene paleo-groundwater as a pristine fresh water resource in southern Germany: Evidence from stable and radiogenic isotopes. Sci. Tot. Environ., 496, 107-115, https://doi. org/10.1016/j.scitotenv.2014.07.011.

45. Spiro, B. et al. (2011). Strontium isotopes in Melanopsis sp. as indicators of variation in hydrology and climate in the Upper Jordan Valley during the Early-Middle Pleistocene, and wider implications. J. Human Evol., 60(4), 407-416, https://doi.org/10.1016/j.jhevol.2010.07.026.

46. Dole, M. (1935). The relative atomic weight of oxygen in water and in air. J. Am. Chem. Soc., 57(12), 2731-2731, https://doi.org/10.1021/ja01315a511.

47. Münnich, K. O. (1957). Heidelberg natural radiocarbon measurements I. Sci., 126(3266), 194-199.

48. Craig, H. (1961). Isotopic variations in meteoric waters. Sci., 133(3465), 1702-1703, https://doi.org/10.1126/science.133.3465.1702.

49. Deodhar, A. S. et al. (2014). Isotope techniques for water resources management. BARC News. Issue, 337, 29-35, https://doi.org/10.12691/ ajwr-3-3-3.

50. Nurin N. A. et al. (2016). Application of biodegradable material in restoring degraded soil system. Paper presented at the International Conference on Sustainable Development Goals 2016, Universiti Sains Malaysia, Pulau Pinang, Malaysia, 7-8 December.

51. Dansgaard, W. (1964). Stable isotopes in precipitation. Tellus, 16(4), 436468, https://doi.org/10.3402/tellusa.v16i4.8993.

52. Rose, T. P., Davisson, M. L. \& Criss, R. E. (1996). Isotope hydrology of voluminous cold springs in fractured rock from an active volcanic region, northeastern California. J. Hydrol., 179(1-4), 207-236, https://doi. org/10.1016/0022-1694(95)02832-3.

53. Davisson, M. L. et al. (1999). Isotope hydrology of southern Nevada groundwater: Stable isotopes and radiocarbon. Water Res. Res., 35(1), 279-294, https://doi.org/10.1029/1998WR900040.

54. Giorgi, F. et al. (1997). Elevation dependency of the surface climate change signal: A model study. J. Clim., 10(2), 288-296, https://doi. org/10.1175/1520-0442(1997)010<0288:EDOTSC $>2.0 . C O ; 2$.

55. Dutton, A. et al. (2005). Spatial distribution and seasonal variation in ${ }^{18} \mathrm{O} /{ }^{16} \mathrm{O}$ of modern precipitation and river water across the conterminous USA. Hydrol. Proc., 19(20), 4121-4146, https://doi.org/10.1002/hyp.5876. 
56. Maloszewski, P. et al. (1995). Isotope hydrology investigations in large refuse lysimeters. J. Hydrol., 167(1-4), 149-166, https://doi.org/10.1016/ 0022-1694(94)02612-F.

57. Sidle, W. C., Arihood, L. \& Bayless, R. (2000). Isotope hydrology dynamics of riverine wetlands in the Kankakee watershed, Indiana. JAWRA J. Amer. Wat. Res. Assoc., 36(4), 771-790, https://doi.org/10.1111/j.17521688.2000.tb04305.x.

58. Vandenschrick, G. et al. (2002). Using stable isotope analysis $\left(\delta \mathrm{D}-\delta^{18} \mathrm{O}\right)$ to characterise the regional hydrology of the Sierra de Gador, south east Spain. J. Hydrol., 265(1), 43-55, https://doi.org/10.1016/S0022-1694 (02)00097-5.

59. Lambs, L. et al. (2005). Oxygen and hydrogen isotopic composition of major Indian rivers: A first global assessment. Hydrol. Proc., 19(17), 3345-3355, https://doi.org/10.1002/hyp.5974.

60. Portugal, E. et al. (2005). The geochemistry and isotope hydrology of the Southern Mexicali Valley in the area of the Cerro Prieto, Baja California (Mexico) geothermal field. J. Hydrol., 313(3), 132-148, https://doi.org/ 10.1016/j.jhydrol.2005.02.027.

61. Blasch, K. W. \& Bryson, J. R. (2007). Distinguishing sources of ground water recharge by using $\delta^{2} \mathrm{H}$ and $\delta^{18} \mathrm{O}$. Groundwat., 45(3), 294-308, https://doi.org/10.1111/j.1745-6584.2006.00289.x.

62. Cobb, K. M. et al. (2007). Regional-scale climate influences on temporal variations of rainwater and cave dripwater oxygen isotopes in northern Borneo. Earth Plan. Sci. Lett., 263(3), 207-220, https://doi.org/10.1016/j. eps1.2007.08.024.

63. Ferguson, P. R. et al. (2007). Isotope constraints on water, carbon, and heat fluxes from the northern Great Plains region of North America. Glob. Biogeochem. Cycles, 21(2), https://doi.org/10.1029/2006GB002702.

64. Rock, L. \& Mayer, B. (2007). Isotope hydrology of the Oldman River basin, southern Alberta, Canada. Hydrol. Proc., 21(24), 3301-3315, https://doi. org/10.1002/hyp.6545.

65. Tetzlaff, D. et al. (2007). Conceptualization of runoff processes using a geographical information system and tracers in a nested mesoscale catchment. Hydrol. Proc., 21(10), 1289-1307, https://doi.org/10.1002/ hyp.6309.

66. Aji, K. et al. (2008). Characteristics of chemistry and stable isotopes in groundwater of Chaobai and Yongding River basin, North China Plain. Hydrol. Proc., 22(1), 63-72, https://doi.org/10.1002/hyp.6640.

67. Freitag, H. et al. (2008). Water and carbon fluxes from savanna ecosystems of the Volta River watershed, West Africa. Glob. Planet. Chg., 61(1), 3-14, https://doi.org/10.1016/j.gloplacha.2007.08.003. 
68. Kabeya, N. et al. (2008). Isotopic investigation of river water mixing around the confluence of the Tonle Sap and Mekong rivers. Hydrol. Proc., 22(9), 1351-1358, https://doi.org/10.1002/hyp.6944.

69. Karim, A., Veizer, J. \& Barth, J. (2008). Net ecosystem production in the Great Lakes basin and its implications for the North American missing carbon sink: A hydrologic and stable isotope approach. Glob. Plan. Chg., 61(1), 15-27, https://doi.org/10.1016/j.gloplacha.2007.08.004.

70. Brunet, F. et al. (2009). Terrestrial and fluvial carbon fluxes in a tropical watershed: Nyong basin, Cameroon. Chem. Geol., 265(3), 563-572, https://doi.org/10.1016/j.chemgeo.2009.05.020.

71. Massmann, G. et al. (2008). Investigation of groundwater residence times during bank filtration in Berlin: A multi-tracer approach. Hydrol. Proc., 22(6), 788-801, https://doi.org/10.1002/hyp.6649.

72. McIntosh, J. C., Schlegel, M. E. \& Person, M. (2012). Glacial impacts on hydrologic processes in sedimentary basins: Evidence from natural tracer studies. Geofl., 12(1), 7-21, https://doi.org/10.1111/j.1468-8123. 2011.00344.x.

73. Lee, K. Y. et al. (2013). Isotope constraints on the aquatic carbon budget: Langat Watershed, Malaysia. Aquat. Geochem., 19(5-6), 443-475, https://doi.org/10.1007/s10498-013-9198-3.

74. Moerman, J. W. et al. (2013). Diurnal to interannual rainfall $\delta^{18} \mathrm{O}$ variations in northern Borneo driven by regional hydrology. Earth Plan. Sci. Lett., 369, 108-119, https://doi.org/10.1016/j.eps1.2013.03.014.

75. Syakir, M. I. (2014). A reconnaissance study of water and carbon flux in tropical watershed of Peninsular Malaysia: Stable isotope constraints. PhD diss., University of Ottawa, Canada.

76. Tetzlaff, D. et al. (2015). A preliminary assessment of water partitioning and ecohydrological coupling in northern headwaters using stable isotopes and conceptual runoff models. Hydrol. Proc., 29(25), 5153-5173, https://doi.org/10.1002/hyp.10515.

77. Lawrence, J. R. (1998). Isotopic spikes from tropical cyclones in surface waters: Opportunities in hydrology and paleoclimatology. Chem. Geol., 144(1), 153-160, https://doi.org/10.1016/S0009-2541(97)00090-9.

78. Björck, S. et al. (2000). Eemian Lake development, hydrology and climate: A multi-stratigraphic study of the Hollerup site in Denmark. Quat. Sci. Rev., 19(6), 509-536, https://doi.org/10.1016/S0277-3791(99)00025-6.

79. Cross, S. L. et al. (2001). Late quaternary climate and hydrology of tropical South America inferred from an isotopic and chemical model of Lake Titicaca, Bolivia and Peru. Quat. Res., 56(1), 1-9, https://doi.org/10.1006/ qres.2001.2244. 
80. Li, H. C. et al. (2004). Climate and hydrology of the Last Interglaciation (MIS 5) in Owens Basin, California: Isotopic and geochemical evidence from core OL-92. Quat. Sci. Rev., 23(1), 49-63, https://doi.org/10.1016/ S0277-3791(03)00215-4.

81. Eastwood, W. J. et al. (2007). Holocene climate change in the eastern Mediterranean region: A comparison of stable isotope and pollen data from Lake Gölhisar, southwest Turkey. J. Quat. Sci., 22(4), 327-341, https://doi. org/10.1002/jqs. 1062.

82. Roberts, N. et al. (2008). Stable isotope records of late quaternary climate and hydrology from Mediterranean lakes: The ISOMED synthesis. Quat. Sci. Rev., 27(25), 2426-2441, https://doi.org/10.1016/j.quascirev. 2008.09.005.

83. Wolfe, B. B. et al. (2008). Hydroecological responses of the Athabasca Delta, Canada, to changes in river flow and climate during the 20th century. Ecohydr., 1(2), 131-148, https://doi.org/10.1002/eco.13.

84. Large, D. J. et al. (2009). The influence of climate, hydrology and permafrost on Holocene peat accumulation at $3500 \mathrm{~m}$ on the eastern Qinghai-Tibetan plateau. Quat. Sci. Rev., 28(27), 3303-3314, https://doi.org/10.1016/j. quascirev.2009.09.006.

85. Cockerton, H. E. et al. (2013). Stable-isotope (H, O, and Si) evidence for seasonal variations in hydrology and Si cycling from modern waters in the Nile Basin: Implications for interpreting the quaternary record. Quat. Sci. Rev., 66, 4-21, https://doi.org/10.1016/j.quascirev.2012.12.005.

86. Klein, E. S. et al. (2013). Hydrology-mediated differential response of carbon accumulation to late Holocene climate change at two peatlands in Southcentral Alaska. Quat. Sci. Rev., 64, 61-75, https://doi.org/10.1016/j. quascirev.2012.12.013.

87. Pérez, L. et al. (2013). Stable isotope values $\left(\delta^{18} \mathrm{O} \& \delta^{13} \mathrm{C}\right)$ of multiple ostracode species in a large Neotropical lake as indicators of past changes in hydrology. Quat. Sci. Rev., 66, 96-111, https://doi.org/10.1016/j. quascirev.2012.10.044.

88. Peng, T. R. et al. (2007). Using hydrogen, oxygen, and tritium isotopes to identify the hydrological factors contributing to landslides in a mountainous area, central Taiwan. Environ. Geol., 52(8), 1617-1629, https://doi. org/10.1007/s00254-006-0607-4.

89. Brock, B. E., Wolfe, B. B. \& Edwards, T. W. D. (2008). Spatial and temporal perspectives on spring break-up flooding in the Slave River delta, NWT. Hydrol. Proc., 22(20), 4058-4072, https://doi.org/10.1002/hyp.7008.

90. Brunet, F. et al. (2005). $\delta^{13} \mathrm{C}$ tracing of dissolved inorganic carbon sources in Patagonian rivers (Argentina). Hydrol. Proc., 19(17), 3321-3344, https://doi.org/10.1002/hyp.5973. 
91. Yang, Q. et al. (2011). Hydrological and isotopic characterization of river water, groundwater, and groundwater recharge in the Heihe River basin, northwestern China. Hydrol. Proc., 25(8), 1271-1283, https://doi. org/10.1002/hyp.7896.

92. Anzalone, E. et al. (2007). Travertines as hydrologic archives: The case of the Pontecagnano deposits (southern Italy). Adv. Wat. Res., 30(10), 21592175, https://doi.org/10.1016/j.advwatres.2006.09.008.

93. Vasiliev, I., Reichart, G. J. \& Krijgsman, W. (2013). Impact of the Messinian Salinity Crisis on Black Sea hydrology: Insights from hydrogen isotopes analysis on biomarkers. Earth Plan. Sci. Lett., 362, 272-282, https://doi. org/10.1016/j.epsl.2012.11.038.

94. Kusakabe, M., Ohsumi, T. \& Aramaki, S. (1989). The Lake Nyos gas disaster: Chemical and isotopic evidence in waters and dissolved gases from three Cameroonian crater lakes, Nyos, Monoun and Wum. $J$. Volcanol. Geotherm. Res., 39(2), 167-185, https://doi.org/10.1016/03770273(89)90056-5.

95. Zhang, J. et al. (1995). Water geochemistry of the rivers around the Taklimakan Desert (NW China): Crustal weathering and evaporation processes in arid land. Chem. Geol., 119(1), 225-237, https://doi. org/10.1016/0009-2541(94)00088-P.

96. Frei, K. M. \& Frei, R. (2011). The geographic distribution of strontium isotopes in Danish surface waters: A base for provenance studies in archaeology, hydrology and agriculture. Appl. Geochem., 26(3), 326-340, https://doi.org/10.1016/j.apgeochem.2010.12.006.

97. Grove, M. J. et al. (2003). Application of strontium isotopes to understanding the hydrology and paleohydrology of the Altiplano, Bolivia, Peru. Palaeog. Palaeoclim. Palaeoecol., 194(1), 281-297, https://doi.org/10.1016/S00310182(03)00282-7.

98. Wilhams, M. W. et al. (1995). Controls on the major ion chemistry of the Ürümqi River, Tian Shan, People's Republic of China. J. Hydrol., 172(1-4), 209-229, https://doi.org/10.1016/0022-1694(95)02702-Q.

99. Gat, J. R. (2010). Isotope hydrology: A study of the water cycle, vol. 6. Singapore: World Scientific.

100. Logan, B., Taffs, K. H. \& Cunningham, L. (2010). Applying paleolimnological techniques in estuaries: A cautionary case study from Moreton Bay, Australia. Mar. Freshwat. Res., 61(9), 1039-1047, https://doi.org/10.1071/MF09277. 
101. Moya, C. E. et al. (2016). Using environmental isotopes and dissolved methane concentrations to constrain hydrochemical processes and interaquifer mixing in the Galilee and Eromanga Basins, Great Artesian Basin, Australia. J. Hydrol., 539, 304-318, https://doi.org/10.1016/j. jhydrol.2016.05.016.

102. Vollstaedt, H. et al. (2014). The Phanerozoic $\delta^{88 / 86} \mathrm{Sr}$ record of seawater: New constraints on past changes in oceanic carbonate fluxes. Geochim. Cosmochim. Acta, 128, 249-265, https://doi.org/10.1016/j.gca.2013.10. 006.

103. Stadler, S. et al. (2010). Groundwater flow regime, recharge and regionalscale solute transport in the semi-arid Kalahari of Botswana derived from isotope hydrology and hydrochemistry. J. Hydrol., 388(3), 291-303, https://doi.org/10.1016/j.jhydrol.2010.05.008.

104. Lamontagne, S. et al. (2015). River infiltration to a subtropical alluvial aquifer inferred using multiple environmental tracers. Wat. Res. Res., 51(6), 4532-4549, https://doi.org/10.1002/2014WR015663.

105. Cotel, A. J. (1999). A trigger mechanism for the Lake Nyos disaster. J. Volcan. Geotherm. Res., 88(4), 343-347, https://doi.org/10.1016/S03770273(99)00017-7.

106. Kamtchueng, B. T. et al. (2015). A multi-tracer approach for assessing the origin, apparent age and recharge mechanism of shallow groundwater in the Lake Nyos catchment, Northwest, Cameroon. J. Hydrol., 523, 790-803, https://doi.org/10.1016/j.jhydrol.2015.02.008.

107. Shou, K., Chen, Y. \& Liu, H. (2009). Hazard analysis of Li-shan landslide in Taiwan. Geomorph., 103(1), 143-153, https://doi.org/10.1016/j. geomorph.2007.09.017.

108. Brock, B. E. et al. (2009). Multi-year landscape-scale assessment of lakewater balances in the Slave River Delta, NWT, using water isotope tracers. J. Hydrol., 379(1), 81-91, https://doi.org/10.1016/j.jhydrol.2009. 09.046 .

109. Syakir, M. I. et al. (2016). Isotopic fingerprint of $\delta^{18} \mathrm{O}$ and $\delta^{2} \mathrm{H}$ in tropical precipitation: A complementary to flood forensic study in Kelantan. Paper presented at the 7th International Conference on Water Resources and Environment Research (ICWRER2016) Kyoto TERRSA, Kyoto, 5-9 June.

110. Craig, H. \& Gordon, L. I. (1965). Deuterium and oxygen 18 variations in the ocean and the marine atmosphere. Proc. Stab. Isot. Oceanogr. Stud. Paloetemp., 9-130.

111. Friedman, I. \& O'Neil, J. R. (1977). Data of geochemistry: Compilation of stable isotope fractionation factors of geochemical interest, vol. 440. Washington: US Government Printing Office. 
112. Gibson, J. J. et al. (1993). Estimating evaporation using stable isotopes: Quantitative results and sensitivity analysis for two catchments in northern Canada. Hydrol. Res., 24(2-3), 79-94.

113. Araguás-Araguás, L., Froehlich, K. \& Rozanski, K. (1998). Stable isotope composition of precipitation over southeast Asia.J. Geophys. Res. Atmosph., 103(D22), 28721-28742, https://doi.org/10.1029/98JD02582.

114. Gibson, J. J. \& Edwards, T. W. D. (2002). Regional water balance trends and evaporation-transpiration partitioning from a stable isotope survey of lakes in northern Canada. Glob. Biogeochem. Cyc., 16(2), https://doi. org/10.1029/2001GB001839.

115. Henderson-Sellers, A. et al. (2004). Using stable water isotopes to evaluate basin-scale simulations of surface water budgets. J. Hydromet., 5(5), 805-822, https://doi.org/10.1175/1525-7541(2004)005<0805:USWITE $>$ 2.0.CO;2.

116. Fekete, B. M. et al. (2006). Application of isotope tracers in continental scale hydrological modeling. J. Hydrol., 330(3), 444-456, https://doi.org/ 10.1016/j.jhydrol.2006.04.029.

117. Adikari, Y. \& Yoshitani, J. (2009). Global trends in water-related disasters: An insight for policymakers. Paris: UNESCO. 